\title{
Graphene-modified Pd/C cathode and Pd/GAC particles for enhanced electrocatalytic removal of bromate in a continuous three-dimensional electrochemical reactor
}

\author{
Ran Mao ${ }^{a, b}, \mathrm{Xu}$ Zhao $^{a}$, Huachun Lan ${ }^{a}$, Huijuan Liu ${ }^{a}$, Jiuhui Qu ${ }^{a, *}$ \\ ${ }^{a}$ Key Laboratory of Drinking Water Science and Technology, Research Center for Eco-Environmental Sciences, \\ Chinese Academy of Sciences, Beijing, 100085, PR China \\ ${ }^{\mathrm{b}}$ University of Chinese Academy of Sciences, Beijing, 100049, PR China
}

\section{A R T I C L E I N F O}

\section{Article history:}

Received 6 December 2014

Received in revised form

4 March 2015

Accepted 4 March 2015

Available online 14 March 2015

Keywords:

Electrocatalytic reduction

Bromate removal

$\mathrm{Pd}-\mathrm{rGO} / \mathrm{C}$ electrode

$\mathrm{Pd}-\mathrm{rGO} / \mathrm{GAC}$

Three-dimensional electrochemical reactor

\begin{abstract}
A B S T R A C T
Bromate $\left(\mathrm{BrO}_{3}{ }^{-}\right)$is a carcinogenic and genotoxic contaminant commonly generated during ozonation of bromide-containing water. In this work, the reductive removal of $\mathrm{BrO}_{3}{ }^{-}$in a continuous three-dimensional electrochemical reactor with palladium-reduced graphene oxide modified carbon paper (Pd-rGO/C) cathode and Pd-rGO modified granular activated carbon (Pd-rGO/GAC) particles was investigated. The results indicated that the rGO sheets significantly promoted the electrochemical reduction of $\mathrm{BrO}_{3}{ }^{-}$. With the enhanced electron transfer by $\mathrm{rGO}$ sheets, the electroreduction of $\mathrm{H}_{2} \mathrm{O}$ to atomic $\mathrm{H}^{*}$ on the polarized Pd particles could be significantly accelerated, leading to a faster reaction rate of $\mathrm{BrO}_{3}{ }^{-}$with atomic $\mathrm{H}^{*}$. The synergistic effect of the Pd-rGO/C cathode and Pd-rGO/GAC particles were also exhibited. The atomic $\mathrm{H}^{*}$ involved in various electroreduction processes was detected by electron spin resonance spectroscopy and its role for $\mathrm{BrO}_{3}{ }^{-}$reduction was determined. The performance of the reactor was evaluated in terms of the removal of $\mathrm{BrO}_{3}{ }^{-}$and the yield of $\mathrm{Br}^{-}$as a function of the GO concentration, Pd loading amount, current density, hydraulic residence time ( $\mathrm{HRT}$ ), and initial $\mathrm{BrO}_{3}{ }^{-}$concentration. Under the current density of $0.9 \mathrm{~mA} / \mathrm{cm}^{2}, \mathrm{BrO}_{3}{ }^{-}$with the initial concentration of $20 \mu \mathrm{g} / \mathrm{L}$ was reduced to be less than $6.6 \mu \mathrm{g} / \mathrm{L}$ at the HRT of $20 \mathrm{~min}$. The $\mathrm{BrO}_{3}{ }^{-}$reduction was inhibited in the presence of dissolved organic matter. Although the precipitates generated from $\mathrm{Ca}^{2+}$ and $\mathrm{Mg}^{2+}$ in the tap water would cover the Pd catalysts, a long-lasting electrocatalytic activity could be maintained for the $30 \mathrm{~d}$ treatment. SEM and XPS analysis demonstrated that the precipitates were predominantly deposited onto the Pd-rGO/C cathode rather than the Pd-rGO/GAC particles.
\end{abstract}

(C) 2015 Elsevier Ltd. All rights reserved.

\footnotetext{
* Corresponding author. Tel.: +86 10 62849151; fax: +861062923558.

E-mail address: jhqu@rcees.ac.cn (J. Qu). http://dx.doi.org/10.1016/j.watres.2015.03.002

0043-1354/@ 2015 Elsevier Ltd. All rights reserved.
} 


\section{Introduction}

Bromate $\left(\mathrm{BrO}_{3}{ }^{-}\right)$is an oxyhalide disinfection byproduct usually generated during ozonation in water supplies (Weinberg et al., 2003). It has been shown recently, that $\mathrm{BrO}_{3}{ }^{-}$can also be formed in distribution systems by metal-oxide catalysis of $\mathrm{HOBr}$ disproportionation (Liu et al., 2013). Due to its carcinogenic and genotoxic properties, many countries have promulgated a $10 \mu \mathrm{g} / \mathrm{L}$ standard of $\mathrm{BrO}_{3}{ }^{-}$in drinking water (Butler et al., 2005; Huang et al., 2014). To meet this strict limitation, various kinds of methods have been developed to eliminate $\mathrm{BrO}_{3}{ }^{-}$, including filtration, chemical reduction, activated carbon techniques, and biological remediation (Kirisits et al., 2001; Li et al., 2010; Listiarini et al., 2010; Matos et al., 2008). Generally, second pollution and high consumption of reagents are inevitable in the removal process (Butler et al., 2005). It was reported by Paschoal et al. (2009) that photoelectrocatalysis using a negatively applied potential to an irradiated $\mathrm{TiO}_{2}$-coated photocathode could be used to selectively reduce $\mathrm{BrO}_{3}{ }^{-}$to $\mathrm{Br}^{-}$, which was a good process with a high level of $\mathrm{BrO}_{3}{ }^{-}$conversion.

Electrochemical reductive treatment has been recognized as a promising method for eliminating $\mathrm{BrO}_{3}{ }^{-}$due to its rapid reaction rate, mild reaction conditions and the absence of recalcitrant secondary contaminants (Kishimoto and Matsuda, 2009; Ding et al., 2010; Radjenovic et al., 2012). $\mathrm{BrO}_{3}{ }^{-}$can be transformed to nontoxic $\mathrm{Br}^{-}$by the reduction at the cathode. In the electrochemical reduction process, the cathode materials are considered as the most critical parameter because of its predominant influence on reaction pathway and treatment efficiency (Comninellis and Chen, 2010; Sun et al., 2014). Several electrode materials catalyzing $\mathrm{BrO}_{3}{ }^{-}$reduction were reported such as tungsten oxide (Casella and Contursi, 2005), activated carbon felt (Kishimoto and Matsuda, 2009), polyaniline-modified electrode (Ding et al., 2010), and phosphomolybdate-modified multi-walled carbon nanotubes (Skunik and Kulesza, 2009). However, the application of these cathodes for water treatment would be limited due to the low $\mathrm{A} / \mathrm{V}$ ratio (ratio of the electrode area and solution volume). It has been recognized that the removal rate of the target compounds could be enhanced by using three-dimensional electrode with extensive specific surface area, and thereby more sufficient reactive sites and electrons as compared to other conventional twodimensional electrodes (Kong et al., 2006; Mascia et al., 2012). In the three-dimensional electrochemical reactor, granular activated carbon (GAC) was frequently employed as the particle electrode owing to its fascinating features including low cost, chemical stability, and high surface area (Wei et al., 2010). The major drawback to GAC is the poor electrical conductivity, which would inevitably increase the energy consumption during the electrochemical process. Thus, the modification of GAC is highly desirable for the efficient removal of the pollutants in the three-dimensional electrochemical reactor. For the water treatment applications, some new and modified GAC, such as NanoFe-loaded GAC (Zelmanov and Semiat, 2014), and ammonia-treated GAC (Cheng et al., 2005) were synthesized so as to improve the surface properties.
Graphene is a monolayer of carbon atoms arranged in a two-dimensional honeycomb network. It shows many intriguing properties such as high surface area, excellent electrical conductivity, and high thermal and chemical stability (Allen et al., 2009; Kim et al., 2012). Graphene can offer substantial benefits with regard to mass transfer and charge transport, by providing shorter effective lengths for both ionic and electronic transport (Li et al., 2009). On the other hand, palladium $(\mathrm{Pd})$ has been reported to possess excellent properties to facilitate electrocatalytic reduction due to its superior ability to form surface-adsorbed atomic $\mathrm{H}^{*}$, a highly activated intermediate hydrogen radical (Li et al., 2012). The $\mathrm{Pd}-\mathrm{H}$ bonds are based on multiple $\sigma$-bonding between the hydrogen atoms and the $\mathrm{d}$ orbitals of the $\mathrm{Pd}$ atoms (Conner and Falconer, 1995). Hybridization of metal catalysts with graphene has been applied in many fields such as light emitting diodes, field-effect transistors, solar cells, supercapacitors, batteries, and sensors (Yen et al., 2011; Huang et al., 2012; Sridhar et al., 2012).

To utilize the excellent electrical conductivity of graphene and the unique reactivity of Pd particles for water treatment uses, the Pd-reduced graphene oxide (rGO) modified granular activated carbon (Pd-rGO/GAC) was prepared for the first time and was used as particle electrode for the cathode cell. The PdrGO modified carbon paper (Pd-rGO/C) was used as the cathode. The objective of the present research was to establish a continuous three-dimensional electrochemical reactor for the removal of $\mathrm{BrO}_{3}{ }^{-}$with a typical concentration in water treatment and investigate its applicability in a realistic water matrix. The reactor was carefully designed in order to increase the $\mathrm{A} / \mathrm{V}$ ratio and thus improve the mass transfer of the system. The results showed that the combination of the Pd-rGO/C cathode and Pd-rGO/GAC particles in the cathode cell exhibited a high electrocatalytic activity toward the $\mathrm{BrO}_{3}{ }^{-}$removal, highlighting the potential of three-dimensional electrochemical reactor as an effective system for eliminating $\mathrm{BrO}_{3}$ contamination in water.

\section{Materials and methods}

\subsection{Fabrication of the Pd-rGO/C cathode and Pd-rGO/ GAC}

The Pd-rGO/C electrode was prepared through our previously reported in situ chemical reduction method followed by electrochemically depositing Pd particles (Mao et al., 2014). Briefly, the cleaned carbon paper was first heated at $400{ }^{\circ} \mathrm{C}$ for $5 \mathrm{~h}$ to increase the surface oxygenated functional groups, and thereby increase the impregnation in GO dispersion. Then it was sonicated in the GO suspension for $5 \mathrm{~h}$. The concentration of the GO dispersion was $2.0 \mathrm{mg} / \mathrm{mL}$ unless otherwise noted. Subsequently, the GO film coated carbon paper was transferred to $10.0 \mathrm{mg} / \mathrm{mL}$ ascorbic acid. The reaction system was allowed to remain undisturbed overnight and then heated at $60{ }^{\circ} \mathrm{C}$ for $2 \mathrm{~h}$. After chemical reduction of the GO film, the Pd nanoparticles were electrodeposited on the rGO/C electrode from aqueous solutions of $10 \mathrm{mM} \mathrm{NH}_{4} \mathrm{Cl}$ containing $1 \mathrm{mM}$ $\mathrm{PdCl}_{2}(\mathrm{pH}=1)$ as precursor at a constant current of $0.02 \mathrm{~A}$ for $10 \mathrm{~min}$. The Pd-rGO/GAC was prepared using the same 
chemical reduction procedure to fabricate the rGO sheets, which was followed by impregnation and calcination process for the Pd deposition. Prior to the rGO fabrication, GAC was firstly immersed in a $2.5 \%(\mathrm{w} / \mathrm{w})$ nitric acid solution with the magnetic stirrer, and then was washed and calcined at $200{ }^{\circ} \mathrm{C}$ for $2 \mathrm{~h}$. The rGO coated GAC was then immersed in $\mathrm{PdCl}_{2}$ solution which contained $0.1 \mathrm{M}$ hydrochloric acid, and was ultrasonically treated for $6 \mathrm{~h}$. Then, the obtained samples were dried at $120^{\circ} \mathrm{C}$ and calcined at $300^{\circ} \mathrm{C}$ for $2 \mathrm{~h}$, and was finally reduced in hydrogen at $200{ }^{\circ} \mathrm{C}$ for $5 \mathrm{~h}$ (flow rate: $100 \mathrm{~mL} / \mathrm{min}$ ).

\subsection{Three-dimensional electrochemical reactor and the experimental procedure}

The three-dimensional electrochemical reactor was shown in Fig. S1. All electrochemical experiments were carried out in this reactor with two-compartment cells. The anode cell and cathode cell (effective volume $=300 \mathrm{~mL}$ ) were separated by a proton exchange membrane (Nafion117, Dupont). The Pd-rGO/ $C$ electrode served as the cathode with a geometric surface area of $100 \mathrm{~cm}^{2}$, and $\mathrm{RuO}_{2} / \mathrm{Ti}$ electrode with the same area was employed as the anode. The Pd-rGO/GAC particles were used as fixed filler of the cathode cell with a total effective volume of $100 \mathrm{~mL}$. The distance between the cathode and anode was $4 \mathrm{~cm}$. The reactor was controlled by a DC power supply source AMERLLPS302A (Dahua instrument corporation of Beijing).

$\mathrm{BrO}_{3}{ }^{-}$-spiked tap water was used to investigate the removal capability of the above reactor. The electrochemical experiment was performed in a continuous flow mode at a constant current density. The influent with a given concentration of $\mathrm{BrO}_{3}{ }^{-}$was pumped into the reactor from a reservoir with a given rate. At an appropriate time intervals, samples of $2 \mathrm{~mL}$ were taken from the reactor outlet for analysis.

\subsection{Analytical method}

The concentration of $\mathrm{Pd}^{2+}$ in the electrolyte before and after the deposition was measured by the inductively coupled plasma optical emission spectrometer (ICP-OES, PerkinElmer Co.) to quantify the Pd loading amount on the Pd-loaded electrodes and particles. The concentrations of $\mathrm{BrO}_{3}{ }^{-}$and $\mathrm{Br}^{-}$were measured using ion chromatograph (IC, ICS-2000, Dionex, Sunnyvale, CA) equipped with an IonPac AS-19 anion column and an IonPac AG19 guard column. Mobile phase eluant for the IC was $\mathrm{KOH}$ solution, and the flow rate was $1.0 \mathrm{~mL} / \mathrm{min}$. The chromatogram of $\mathrm{BrO}_{3}{ }^{-}$and $\mathrm{Br}^{-}$was obtained under gradient elution conditions (0.0-18.0 $\mathrm{min}$, $10.0 \mathrm{mM} \mathrm{KOH}$; 18.1-26.0 $\mathrm{min}, 35.0 \mathrm{mM} \mathrm{KOH}$; and 26.1-31.0 min, $10.0 \mathrm{mM} \mathrm{KOH})$. The detection limit of $\mathrm{BrO}_{3}{ }^{-}$ and $\mathrm{Br}^{-}$was $0.1 \mu \mathrm{g} / \mathrm{L}$. The $\mathrm{pH}$ was measured using a $9165 \mathrm{BN}$ $\mathrm{pH}$ electrode connected to an Orion-828 pH analyzer (Orion Research, Inc., Beverly, MA). The electron spin resonance (ESR) signals of radicals spin trapped by spin-trap reagent $5,5^{\prime}$ dimethyl-1-pirroline-N-oxide (DMPO, purchased from Sigma Chemical Co.) were detected on a Bruker model ESR 300E spectrometer equipped with a quanta-Ray Nd:YAG laser system as the irradiation source. For atomic $\mathrm{H}^{*}$ measurement, a constant volume of DMPO was added in the electrolyte prior to the measurement so that DMPO-H adduct could be formed immediately when atomic $\mathrm{H}^{*}$ was generated by the electrochemical process. Total organic carbon (TOC) was measured using a Shimadzu TOC analyzer (TOC-VCPH, Shimadzu, Japan). The concentrations of $\mathrm{Ca}^{2+}$ and $\mathrm{Mg}^{2+}$ in the influent and effluent were also determined by the ICP-OES.

\subsection{Electrode characterization}

The morphology of the cathodes and particles were characterized using JSM 6301 scanning electron microscopy (SEM). Xray photoelectron spectroscopy (XPS) analysis was carried out with an ESCALAB 250 photoelectron spectrometer (ThermoFisher Scientific, USA). The specific surface area was measured by nitrogen adsorption using the BET method with a Micromeritics ASAP 2000 (Micromeritics Co., USA) surface area analyzer.
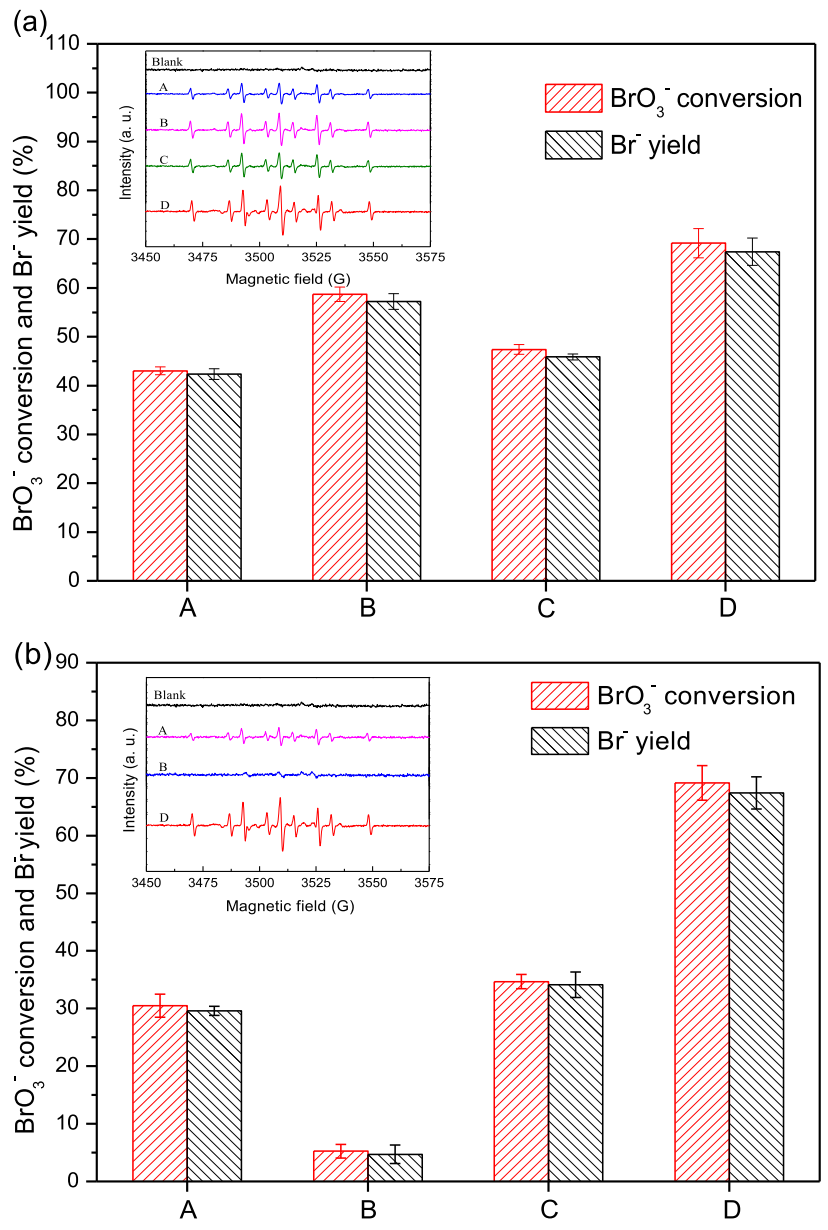

Fig. 1 - (a) The rGO effect on $\mathrm{BrO}_{3}{ }^{-}$removal and $\mathrm{Br}^{-}$yield (A, Pd/C cathode + Pd/GAC; B, Pd-rGO/C cathode + Pd/GAC; C, $\mathrm{Pd} / \mathrm{C}$ cathode + Pd-rGO/GAC; D, Pd-rGO/C cathode + PdrGO/GAC); (b) a comparison of $\mathrm{BrO}_{3}{ }^{-}$removal and $\mathrm{Br}^{-}$yield under various processes (A, Pd-rGO/C cathode; $\mathrm{B}, \mathrm{Pd}-\mathrm{rGO}$ / GAC; C, Pd-rGO/C cathode followed by Pd-rGO/GAC; D, PdrGO/C cathode + Pd-rGO/GAC) (initial $\mathrm{BrO}_{3}$ concentration $=20 \mu \mathrm{g} / \mathrm{L} ; 200 \mathrm{mg} / \mathrm{L} \mathrm{Na}_{2} \mathrm{SO}_{4} ; \mathrm{pH}=7.0$; current density $=0.9 \mathrm{~mA} / \mathrm{cm}^{2} ;$ HRT $=20 \mathrm{~min}$ ). The insets illustrate the DMPO spin-trapping ESR spectra at different treatment processes. 


\section{Results and discussion}

\subsection{The performance of the Pd-rGO/C cathode and Pd-} rGO/GAC on the $\mathrm{BrO}_{3}{ }^{-}$reduction

The comparison of $\mathrm{BrO}_{3}{ }^{-}$removal by the rGO coated and noncoated electrodes (particles) with a fixed Pd loading and current density of $0.9 \mathrm{~mA} / \mathrm{cm}^{2}$ was performed to investigate the role of rGO sheets. As shown in Fig. $1 \mathrm{a}, 43.0 \pm 0.8 \% \mathrm{BrO}_{3}{ }^{-}$ conversion is achieved with the $\mathrm{Pd} / \mathrm{C}$ cathode and $\mathrm{Pd} / \mathrm{GAC}$ particles. By contrast, with the Pd-rGO/C cathode and Pd-rGO/ GAC particles, $\mathrm{BrO}_{3}{ }^{-}$conversion is improved to $69.2 \pm 3 \% . \mathrm{Br}^{-}$ yield is calculated to be less than $1.5 \%$ below the corresponding value of $\mathrm{BrO}_{3}{ }^{-}$conversion throughout the experiments. The negligible gap between $\mathrm{BrO}_{3}{ }^{-}$conversion and $\mathrm{Br}^{-}$ yield indicates that $\mathrm{BrO}_{3}{ }^{-}$is exclusively reduced to $\mathrm{Br}^{-}$. The ESR spin trapping was employed to determine the atomic $\mathrm{H}^{*}$ involved in the electroreduction process. As shown in inset of Fig. 1a, nine characteristic peaks of DMPO-H are observed at different catalysts; no such signals are detected in the black electrolyte. The peak intensities for the processes with different catalysts follow the order of $\mathrm{D}>\mathrm{B}>\mathrm{C}>\mathrm{A}$, coinciding with their electrocatalytic reduction performance. The above results indicate that the addition of rGO on both cathode and particles could result in the enhancement of the generation for atomic $\mathrm{H}^{*}$ in the reactor.
The electrochemical reduction of $\mathrm{BrO}_{3}{ }^{-}$under various processes was also performed. It can be seen in Fig. $1 \mathrm{~b}$ that the removal efficiency by the individual $\mathrm{Pd}-\mathrm{rGO} / \mathrm{C}$ cathode and $\mathrm{Pd}$ rGO/GAC is only $30.5 \pm 2 \%$ and $5.3 \pm 1.2 \%$, respectively. In the process of $\mathrm{Pd}-\mathrm{rGO} / \mathrm{C}$ cathode followed by Pd-rGO/GAC, the improvement in the removal rate is quite slight. However, with the combined process of Pd-rGO/C cathode and Pd-rGO/ $\mathrm{GAC}, \mathrm{BrO}_{3}{ }^{-}$reduction is substantially enhanced with the $\mathrm{BrO}_{3}{ }^{-}$conversion of $69.2 \pm 3 \%$ and $\mathrm{Br}^{-}$yield of $67.4 \pm 2.8 \%$. The peak intensity for the combined process of $\mathrm{Pd}-\mathrm{rGO} / \mathrm{C}$ cathode and Pd-rGO/GAC particles is larger than that for the other three processes (inset in Fig. 1b), suggesting a synergistic effect of the Pd-rGO/C cathode and Pd-rGO/GAC.

Furthermore, it has been reported that tertiary butanol ( $t$ $\mathrm{BuOH})$ can scavenge the hydrogen atoms and convert them into relatively inert 2-methyl-2-propanol radicals (Mezyk et al., 2004). Therefore, the quench experiment using $\mathrm{t}-\mathrm{BuOH}$ was performed here to identify the role of atomic $\mathrm{H}^{*}$ for $\mathrm{BrO}_{3}{ }^{-}$ reduction in the electroreduction process (in a batch mode). As shown in Fig. S2, the removal rate of $\mathrm{BrO}_{3}{ }^{-}$decreases significantly with the increase of the $\mathrm{t}-\mathrm{BuOH}$ concentration. The above results indicate that the electrocatalytic reduction of $\mathrm{BrO}_{3}{ }^{-}$mainly proceeds via the indirect reduction by atomic $\mathrm{H}^{*}$ in the electrochemical reactor.

The reactions on both cathode and particles in the neutral $\mathrm{BrO}_{3}{ }^{-}$solution are illustrated in eqs (1)-(4) (Li and Farrell, 2001; Yang et al., 2007; Mao et al., 2014):
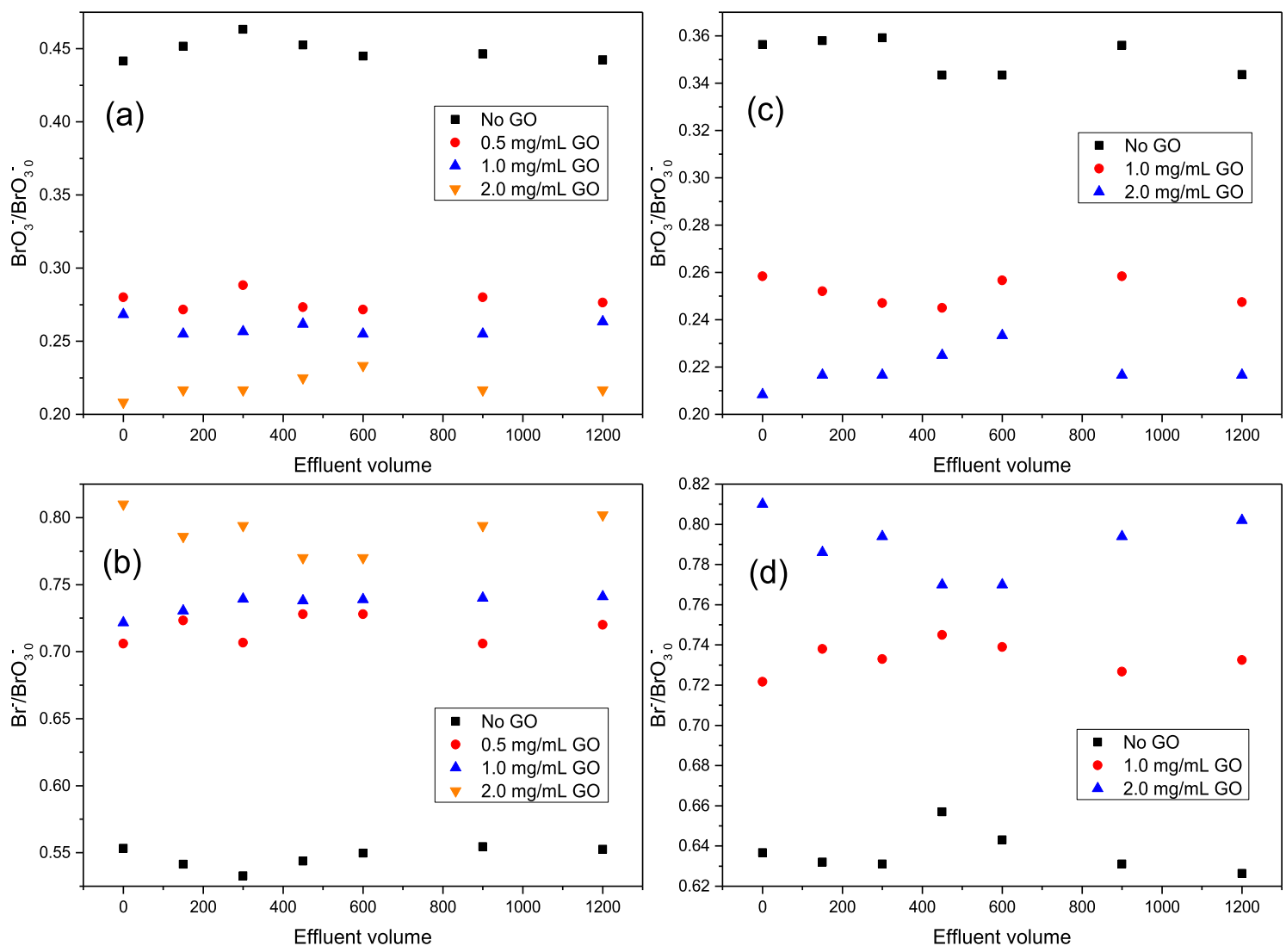

Fig. 2 - (a) Effect of $\mathrm{GO}$ concentration for Pd-rGO/C cathode on $\mathrm{BrO}_{3}{ }^{-}$reduction and (b) $\mathrm{Br}^{-}$generation with $2.93 \mathrm{wt} \% \mathrm{Pd}-\mathrm{rGO} /$ GAC; (c) effect of GO concentration for Pd-rGO/GAC on $\mathrm{BrO}_{3}{ }^{-}$reduction and (d) $\mathrm{Br}^{-}$generation with $0.54 \mathrm{mg} / \mathrm{cm}^{2} \mathrm{Pd}-\mathrm{rGO} / \mathrm{C}$ cathode (initial $\mathrm{BrO}_{3}{ }^{-}$concentration $=20 \mu \mathrm{g} / \mathrm{L} ; 200 \mathrm{mg} / \mathrm{L} \mathrm{Na}_{2} \mathrm{SO}_{4} ; \mathrm{pH}=7.0$; current density $=0.9 \mathrm{~mA} / \mathrm{cm}^{2} ; \mathrm{HRT}=30 \mathrm{~min}$ ). 
$\mathrm{Pd}+\mathrm{H}_{2} \mathrm{O}+\mathrm{e}^{-} \rightarrow \mathrm{Pd}-\mathrm{H}^{*}+\mathrm{OH}^{-}$(Volmer discharge)

$6 \mathrm{Pd}-\mathrm{H}^{*}+\mathrm{BrO}_{3}{ }^{-} \rightarrow 6 \mathrm{Pd}+\mathrm{Br}^{-}+3 \mathrm{H}_{2} \mathrm{O}$ (Hydrodeoxygenation)

$\mathrm{Pd}-\mathrm{H}^{*}+\mathrm{H}_{2} \mathrm{O}+\mathrm{e}^{-} \rightarrow \mathrm{Pd}+\mathrm{H}_{2}+\mathrm{OH}^{-}$(Heyrovsky reaction)

$2 \mathrm{Pd}-\mathrm{H}^{*} \rightarrow 2 \mathrm{Pd}+\mathrm{H}_{2}$ (Tafel recombination)

Due to that the anode cell and cathode cell were separated by a proton exchange membrane, the oxygen evolution reaction in the anode cell would not interference the electroreduction of $\mathrm{BrO}_{3}{ }^{-}$in the reactor and was not shown. Reaction 1 has been recognized as the rate-limiting step for the Pdcatalytic electrochemical reduction process (Li and Farrell, 2001). With the unique electronic structure of rGO sheets, the electroreduction of $\mathrm{H}_{2} \mathrm{O}$ to atomic $\mathrm{H}^{*}$ on the polarized $\mathrm{Pd}$ particles (eq (1)) can be significantly accelerated, leading to a faster reaction rate of $\mathrm{BrO}_{3}{ }^{-}$with atomic $\mathrm{H}^{*}$ (eq (2)). The synergistic effect of the Pd-rGO/C cathode and Pd-rGO/GAC can be attributed to the induced electrons over the Pd-rGO/GAC particles which led to the exponentially increased electron-transfer reaction 1. Therefore, the sufficiently generated atomic $\mathrm{H}^{*}$ on both the Pd-rGO/C cathode and PdrGO/GAC contributes to the efficient $\mathrm{BrO}_{3}{ }^{-}$reduction. In addition, despite the fact that $\mathrm{H}_{2}$ generated on the $\mathrm{Pd}-\mathrm{rGO} / \mathrm{C}$ cathode would retard the mass transfer of $\mathrm{BrO}_{3}{ }^{-}$to the polarized active sites, it can be utilized by the Pd-rGO/GAC (Zhang et al., 2013). This means the activation of $\mathrm{H}_{2}$ by Pd particles on the rGO/GAC can also continuously produce atomic $\mathrm{H}^{*}$, which may be in part responsible for the enhanced reaction rate as compared with the other processes.

The cell potential of the reactor at the current density of $0.9 \mathrm{~mA} / \mathrm{cm}^{2}$ is determined and the data is given in Table S1. It is observed that the cell potential under various processes varies within quite a narrow range of $4.25-4.34 \mathrm{~V}$, suggesting that the cell potential is predominately controlled by the electrolyte conductivity under tested conditions. The unit energy consumption $\mathrm{E}$, expressed in $\mathrm{kWh}$ necessary to removal of $1 \mathrm{mg} \mathrm{BrO}_{3}{ }^{-}$, can be calculated according to

$\mathrm{E}=10^{-3} \mathrm{UItm}^{-1}$

where $\mathrm{U}=$ cell potential $(\mathrm{V}), \mathrm{I}=$ applied current $(\mathrm{A})$, $\mathrm{t}=$ reaction time $(\mathrm{h})$, and $\mathrm{m}=$ mass of the removed target $(\mathrm{mg})$. As can be seen from Table S1, the energy cost for the rGO coated catalysts is lower than that of the non-coated catalysts.
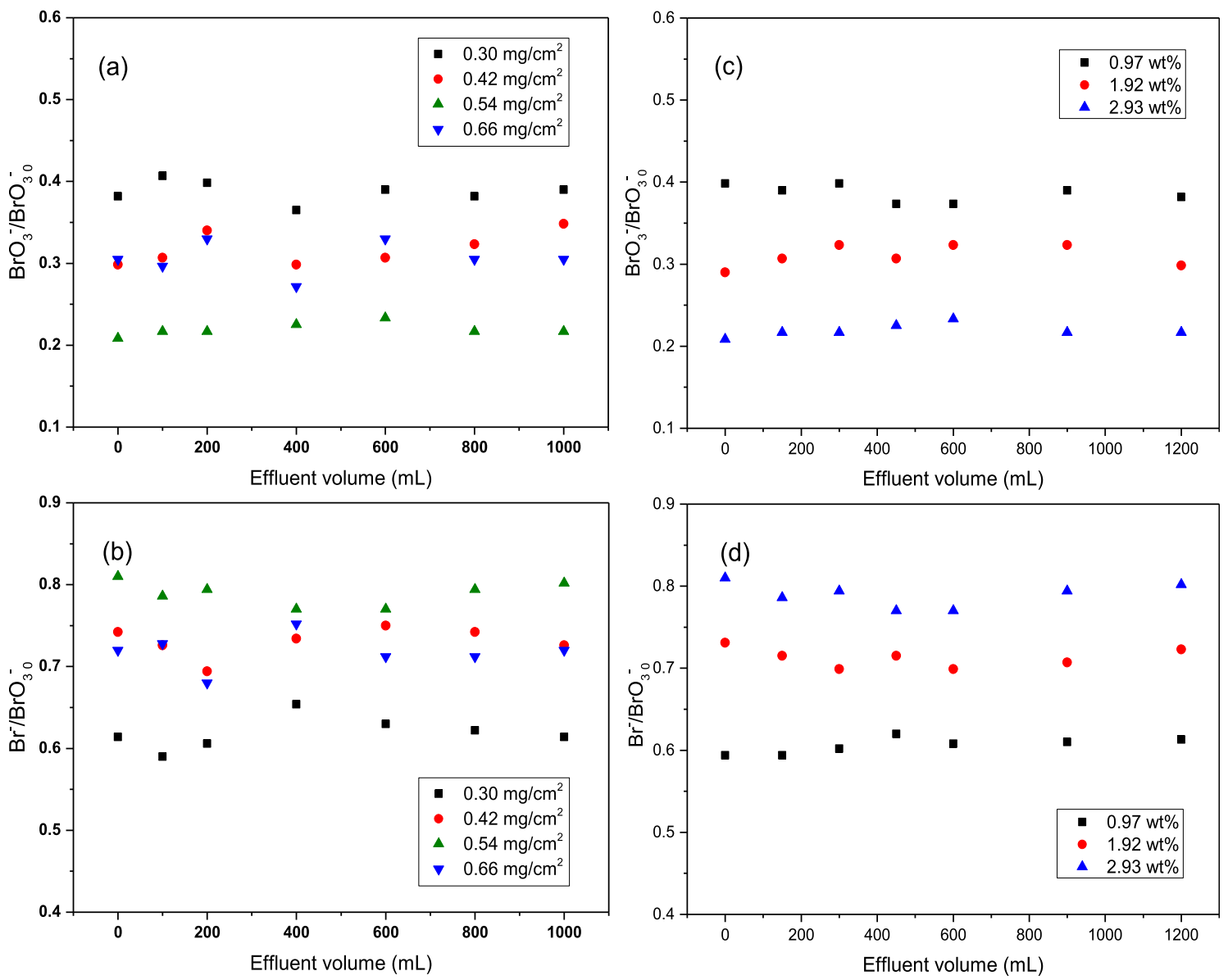

Fig. 3 - (a) Effect of Pd loading amount of Pd-rGO/C cathode on $\mathrm{BrO}_{3}{ }^{-}$reduction and (b) $\mathrm{Br}^{-}$generation with 2.93 wt\% $\mathrm{Pd}-\mathrm{rGO} /$ GAC; (c) effect of Pd loading amount of Pd-rGO/GAC on $\mathrm{BrO}_{3}{ }^{-}$reduction and (d) $\mathrm{Br}^{-}$generation with $0.54 \mathrm{mg} / \mathrm{cm}^{2} \mathrm{Pd}-\mathrm{rGO} / \mathrm{C}$ cathode (initial $\mathrm{BrO}_{3}{ }^{-}$concentration $=20 \mu \mathrm{g} / \mathrm{L} ; 200 \mathrm{mg} / \mathrm{L} \mathrm{Na}_{2} \mathrm{SO}_{4} ; \mathrm{pH}=7.0$; current density $=0.9 \mathrm{~mA} / \mathrm{cm}^{2} ; \mathrm{HRT}=30 \mathrm{~min}$ ). 
Moreover, the combined process of Pd-rGO/C cathode and PdrGO/GAC exhibits the lowest energy cost in comparison with the other processes. The results further confirm that the three-dimensional electrochemical reactor with the Pd-rGO/C cathode and Pd-rGO/GAC particles can be used as an effective system for eliminating $\mathrm{BrO}_{3}{ }^{-}$contamination with a relatively low energy consumption.

\subsection{Effects of GO concentration and Pd loading amount}

The electrocatalytic activity for $\mathrm{BrO}_{3}{ }^{-}$removal are supposed to be related with the concentration of $\mathrm{GO}$ precursor $\left(\mathrm{C}_{\mathrm{GO}}\right)$ since the enhanced effect of the rGO sheets on the electrochemical reduction has been demonstrated. Therefore, the performance of the reactor is also evaluated by controlling $\mathrm{C}_{\mathrm{GO}}$ for fabrication of the Pd-rGO/C cathode and Pd-rGO/GAC, and the results are shown in Fig. 2. When $\mathrm{C}_{\mathrm{GO}}$ for the $\mathrm{Pd}-\mathrm{rGO} / \mathrm{C}$ cathode is increased from 0 to $0.5 \mathrm{mg} / \mathrm{mL}$, the removal efficiency is found to be largely increased from $54.7 \%$ to $72.8 \%$, reflecting that rGO sheets can significantly facilitate the
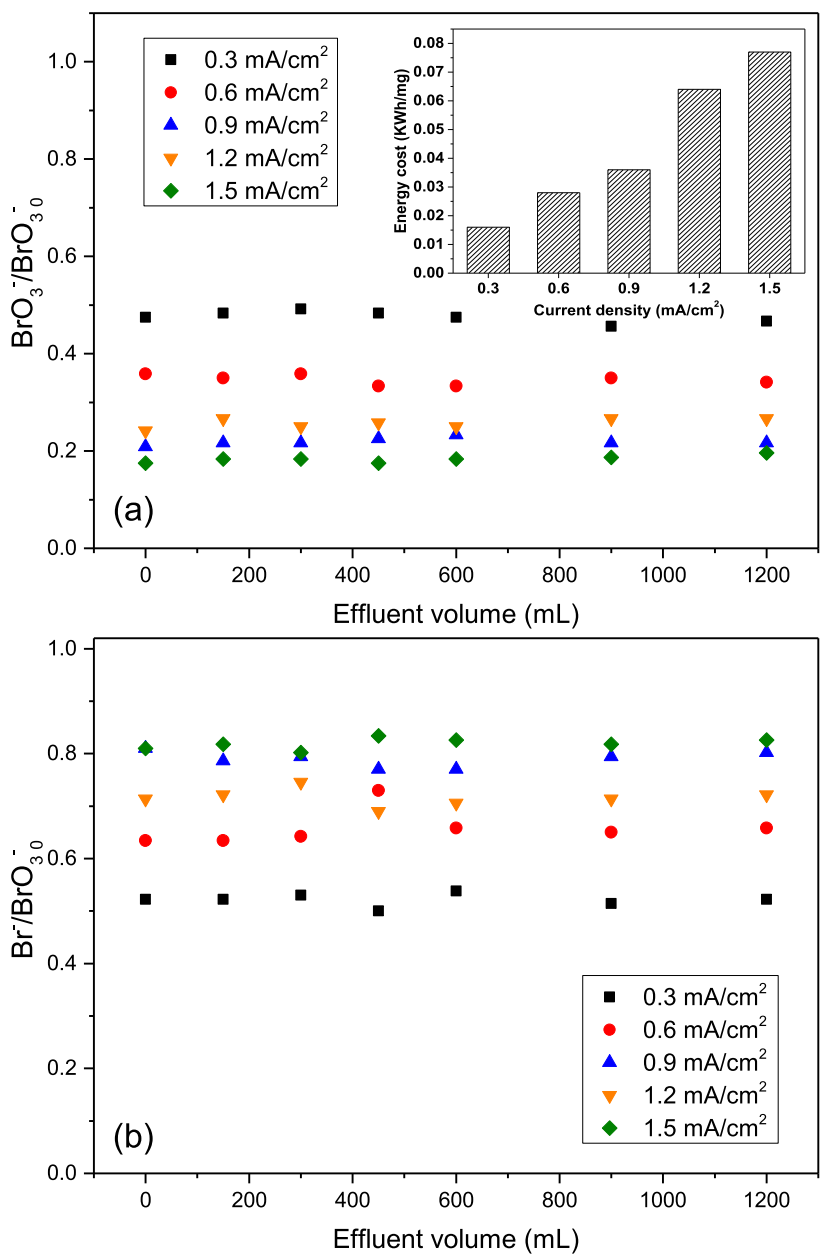

Fig. 4 - Effect of current density on (a) $\mathrm{BrO}_{3}{ }^{-}$reduction and (b) $\mathrm{Br}^{-}$generation $\left(0.54 \mathrm{mg} / \mathrm{cm}^{2} \mathrm{Pd}-\mathrm{rGO} / \mathrm{C}\right.$ cathode, $2.93 \mathrm{wt}$ $\% \mathrm{Pd}-\mathrm{rGO} / \mathrm{GAC}$; initial $\mathrm{BrO}_{3}{ }^{-}$concentration $=20 \mu \mathrm{g} / \mathrm{L}$; $200 \mathrm{mg} / \mathrm{L} \mathrm{Na}_{2} \mathrm{SO}_{4} ; \mathrm{pH}=7.0 ; \mathrm{HRT}=30 \mathrm{~min}$ ). Inset is the energy cost for $\mathrm{BrO}_{3}{ }^{-}$removal with various current densities. electrocatalytic reduction process. Moreover, as $\mathrm{C}_{\mathrm{GO}}$ is further increased to 1.0 and $2.0 \mathrm{mg} / \mathrm{mL}$, a larger amount of $\mathrm{rGO}$ is formed to cover the carbon fibers with the removal efficiency slightly increasing to be $74.2 \%$ and $78.5 \%$, respectively. A similar rising trend in the removal rate is observed when $\mathrm{C}_{\mathrm{GO}}$ of the Pd-rGO/GAC is increased from 0 to $2.0 \mathrm{mg} / \mathrm{mL}$. The obtained results above indicate the high electrocatalytic activities of the $\mathrm{Pd} / \mathrm{rGO} / \mathrm{C}$ electrode and Pd-rGO/GAC prepared by reducing GO dispersions with a wide range of concentrations.

Due to that metallic Pd nanoparticles provide the catalytic active sites and play a significant role in forming atomic $\mathrm{H}^{*}$ to realize indirect $\mathrm{BrO}_{3}{ }^{-}$reduction, the increase of the $\mathrm{Pd}$ loading amount on either Pd-rGO/C cathode or Pd-rGO/GAC is expected to enhance the electrocatalytic reduction. The dependence of $\mathrm{BrO}_{3}{ }^{-}$reduction and $\mathrm{Br}^{-}$generation on the Pd loading amounts is presented in Fig. 3. Upon increasing Pd loading amount on Pd-rGO/C cathode from 0.30 to $0.54 \mathrm{mg} / \mathrm{cm}^{2}$, the $\mathrm{BrO}_{3}{ }^{-}$removal efficiency is increased from $61.9 \%$ to $78.5 \%$. Further increase in the Pd loading amount to $0.66 \mathrm{mg} / \mathrm{cm}^{2}$ results in the decrease in $\mathrm{BrO}_{3}{ }^{-}$removal efficiency and $\mathrm{Br}^{-}$ yield. It has been reported that higher Pd content would cause the serious aggregation of metallic Pd particles and result in locally excessive $\mathrm{H}_{2}$ evolution (An et al., 1998). The cathode
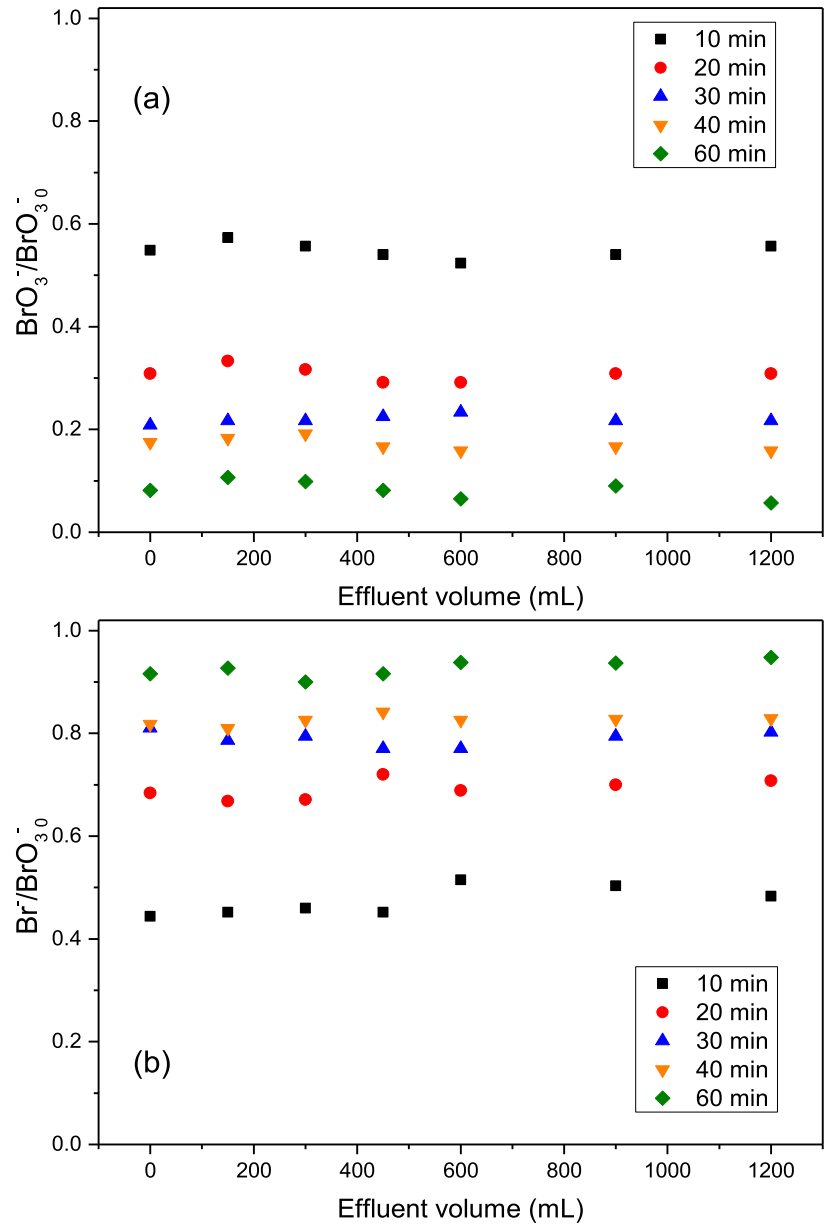

Fig. 5 - Effect of $\mathrm{HRT}$ on (a) $\mathrm{BrO}_{3}{ }^{-}$reduction and (b) $\mathrm{Br}^{-}$ generation $\left(0.54 \mathrm{mg} / \mathrm{cm}^{2} \mathrm{Pd}-\mathrm{rGO} / \mathrm{C}\right.$ cathode, $2.93 \mathrm{wt} \% \mathrm{Pd}-$ rGO/GAC; initial $\mathrm{BrO}_{3}{ }^{-}$concentration $=20 \mu \mathrm{g} / \mathrm{L} ; 200 \mathrm{mg} / \mathrm{L}$ $\mathrm{Na}_{2} \mathrm{SO}_{4} ; \mathrm{pH}=7.0$; current density $=0.9 \mathrm{~mA} / \mathrm{cm}^{2}$ ). 
would then restrict access of $\mathrm{BrO}_{3}{ }^{-}$to the interior portions where $\mathrm{H}_{2}$ is excessively electrogenerated, which can be responsible for the decreased catalytic activity toward $\mathrm{BrO}_{3}{ }^{-}$ reduction. Thus the Pd loading amount on Pd-rGO/C cathode is optimized to be $0.54 \mathrm{mg} / \mathrm{cm}^{2}$.

As for Pd-rGO/GAC, increase of the Pd loading amount in the range from 0.97 to $2.93 \mathrm{wt} \%$ leads to the increase in the rates of $\mathrm{BrO}_{3}^{-}$reduction and $\mathrm{Br}^{-}$generation without the negative influence. The $\mathrm{H}_{2}$ evolution on the Pd-rGO/GAC surface is also observed to be much weaker than that on the PdrGO/C cathode.

\subsection{Effects of current density and hydraulic residence time (HRT)}

The electrocatalytic reduction of $\mathrm{BrO}_{3}{ }^{-}$was performed with various current densities ranging from 0.3 to $1.5 \mathrm{~mA} / \mathrm{cm}^{2}$. It is shown in Fig. 4 that the rates of $\mathrm{BrO}_{3}{ }^{-}$reduction and $\mathrm{Br}^{-}$ generation first increase strongly with the current density increasing from 0.3 to $0.9 \mathrm{~mA} / \mathrm{cm}^{2}$, and then decrease slightly at higher currents. At the current density of $0.9 \mathrm{~mA} / \mathrm{cm}^{2}$, the removal rate of $\mathrm{BrO}_{3}{ }^{-}$is determined to be ca. $78.5 \%$ and $\mathrm{Br}^{-}$ yield can be as high as $78.4 \%$. Corresponding to the current
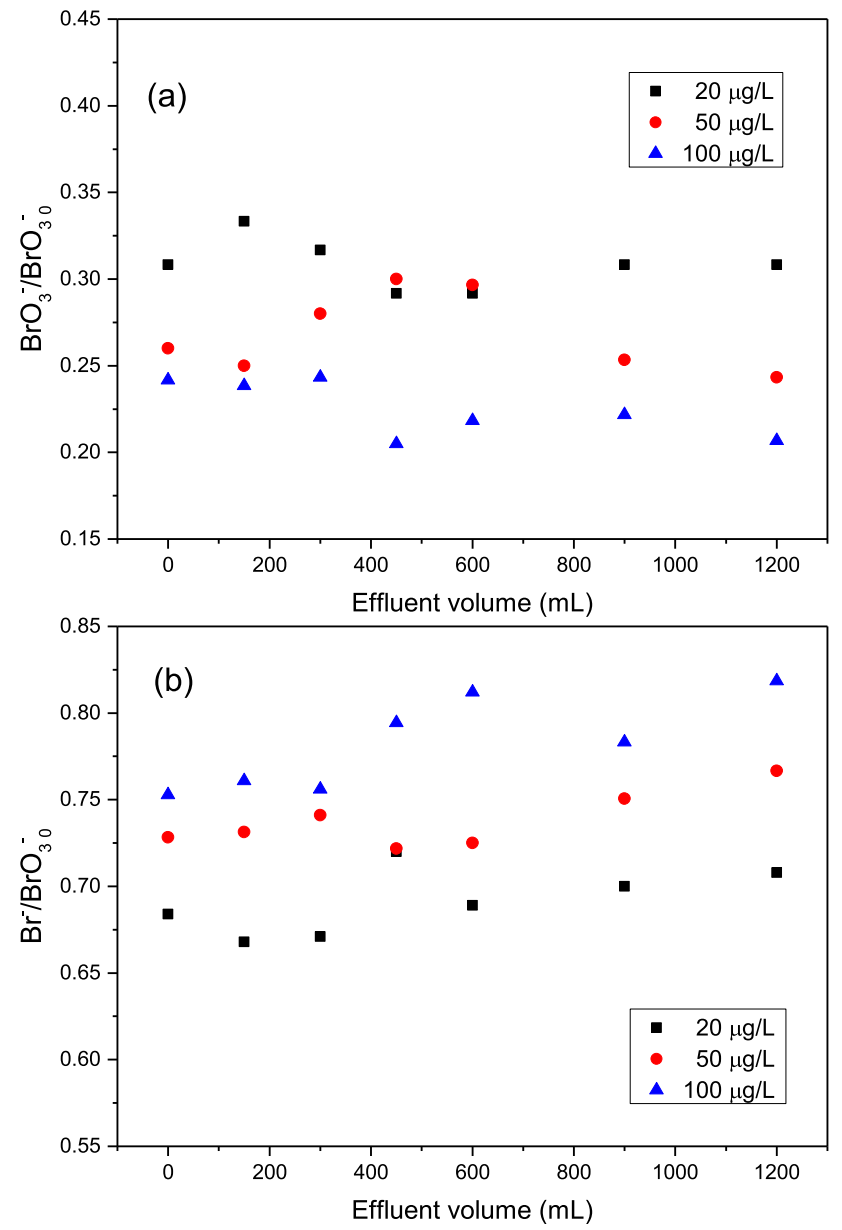

Fig. 6 - Effect of initial $\mathrm{BrO}_{3}{ }^{-}$concentration on (a) $\mathrm{BrO}_{3}$ reduction and (b) $\mathrm{Br}^{-}$generation $\left(0.54 \mathrm{mg} / \mathrm{cm}^{2} \mathrm{Pd}-\mathrm{rGO} / \mathrm{C}\right.$ cathode, 2.93 wt\% Pd-rGO/GAC; 200 mg/L Na $\mathrm{SO}_{4}$; $\mathrm{pH}=7.0$; current density $=0.9 \mathrm{~mA} / \mathrm{cm}^{2} ; \mathrm{HRT}=20 \mathrm{~min}$ ). densities of $0.3,0.6,0.9,1.2$ and $1.5 \mathrm{~mA} / \mathrm{cm}^{2}$, the cell potentials are observed to be $3.4,3.6,4.3,4.8$ and $5.0 \mathrm{~V}$, respectively.

Herein, for the $\mathrm{BrO}_{3}{ }^{-}$reduction proceeding on the $\mathrm{Pd}-\mathrm{rGO} /$ $\mathrm{C}$ electrode and $\mathrm{Pd}-\mathrm{rGO} / \mathrm{GAC}$, the reaction rate $\left(\mathrm{r}_{\mathrm{BrO}_{3}}{ }^{-}\right)$is believed to be associated with the surface coverage of atomic $\mathrm{H}^{*}$ and adsorbed $\mathrm{BrO}_{3}{ }^{-}$, as given by Lipkowski and Ross (1998).

$\mathrm{r}_{\mathrm{BrO}_{3}-}=\mathrm{k}_{\mathrm{BrO}_{3}-} \Theta_{\mathrm{H}}{ }^{\mathrm{n}} \Theta_{\mathrm{BrO}_{3}}$

where $\Theta_{\mathrm{H}}$ and $\Theta_{\mathrm{BrO}_{3}}$ - represent the surface coverage of atomic $\mathrm{H}^{*}$ and adsorbed $\mathrm{BrO}_{3}{ }^{-}$, respectively, and $\mathrm{n}$ is the reaction order of $\mathrm{H}^{*}$ in the hydrodeoxygenation reaction. With the ratelimiting reaction $1, \Theta_{\mathrm{H}}$ increases upon increasing current density, suggesting that more atomic $\mathrm{H}^{*}$ cover the cathode surface which are more likely to be acquired by $\mathrm{BrO}_{3}{ }^{-}$in the solution (Mao et al., 2011). The increased $\mathrm{BrO}_{3}{ }^{-}$reaction rates at higher current densities can be accordingly attributed to the effect of $\Theta_{\mathrm{H}}$. However, the differences in the reduction rate for current density of $0.9,1.2$ and $1.5 \mathrm{~mA} / \mathrm{cm}^{2}$ are slight. This can
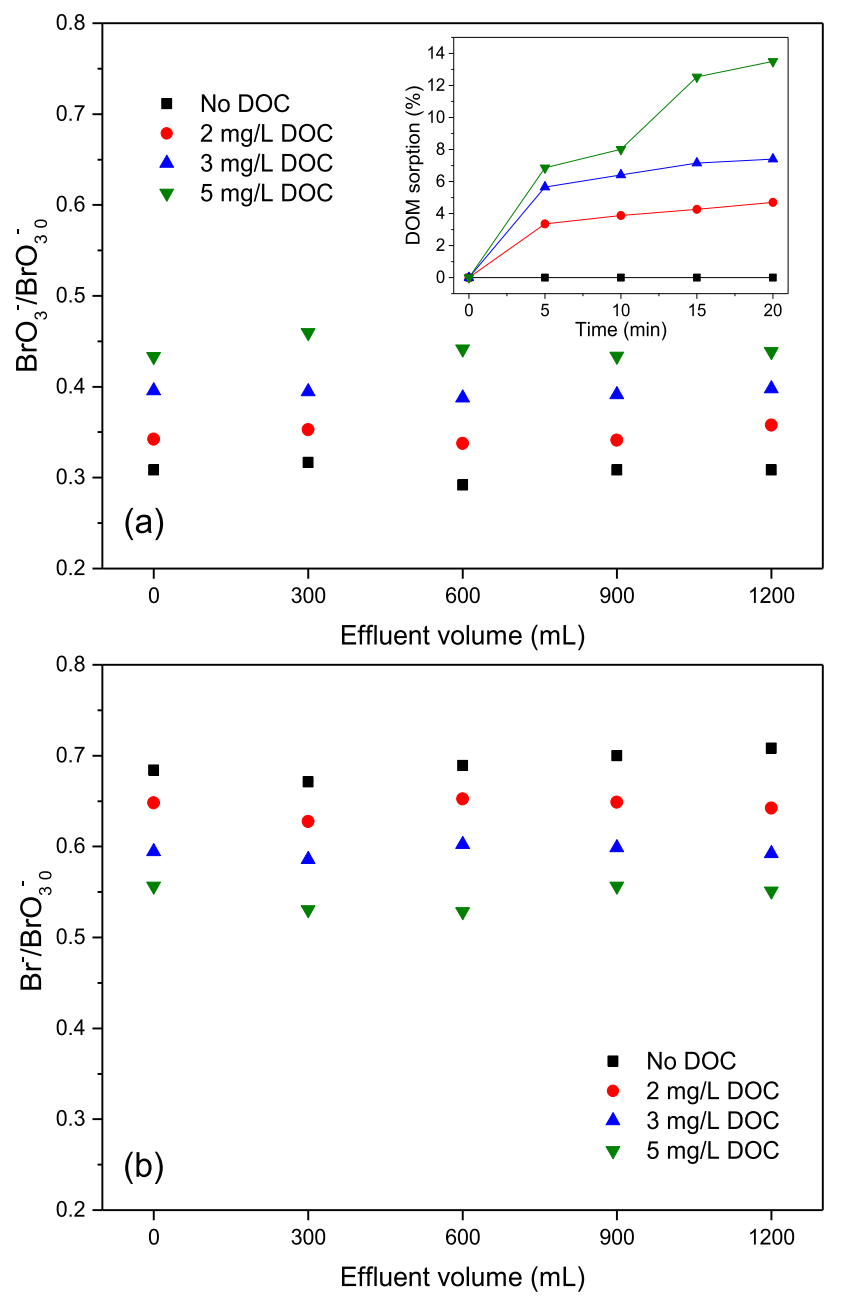

Fig. 7 - Effect of dissolved organic carbon on (a) $\mathrm{BrO}_{3}$ reduction and (b) $\mathrm{Br}^{-}$generation $\left(0.54 \mathrm{mg} / \mathrm{cm}^{2} \mathrm{Pd}-\mathrm{rGO} / \mathrm{C}\right.$ cathode, $2.93 \mathrm{wt} \% \mathrm{Pd}-\mathrm{rGO} / \mathrm{GAC}$; initial $\mathrm{BrO}_{3}$ concentration $=20 \mu \mathrm{g} / \mathrm{L} ; 200 \mathrm{mg} / \mathrm{L} \mathrm{Na}_{2} \mathrm{SO}_{4} ; \mathrm{pH}=7.0$; current density $=0.9 \mathrm{~mA} / \mathrm{cm}^{2} ; \mathrm{HRT}=20 \mathrm{~min}$ ). Inset is the DOM sorption test with the three-dimensional electrochemical reactor. 
be explained by the deactivation of the Pd-rGO/C cathode and Pd-rGO/GAC by the large amount of $\mathrm{H}_{2}$ bubbles at higher currents because further increase of the current densities should lead to faster rate of reaction 3 and 4 . The $\mathrm{H}_{2}$ bubbles would interference the electron transfer or $\mathrm{BrO}_{3}{ }^{-}$diffusion at the electrode surface.

As shown in the inset of Fig. 4, the electric energy consumption increases with increase of the current density. Corresponding to the current densities of 0.3, 0.6, 0.9, 1.2 and $1.5 \mathrm{~mA} / \mathrm{cm}^{2}$, the energy cost is calculated to be $0.016,0.028$, $0.036,0.064$ and $0.077 \mathrm{KWh} / \mathrm{mg}$, respectively. Based on both removal efficiency and energy cost, the current density of $0.9 \mathrm{~mA} / \mathrm{cm}^{2}$ seems the threshold value and is selected for the electrochemical reactor.

The effects of HRT ranging from 10 to 60 min on $\mathrm{BrO}_{3}{ }^{-}$ reduction and $\mathrm{Br}^{-}$generation were investigated with the current density of $0.9 \mathrm{~mA} / \mathrm{cm}^{2}$. As shown in Fig. 5, the removal efficiency of $\mathrm{BrO}_{3}{ }^{-}$and $\mathrm{Br}^{-}$yield at HRT $10 \mathrm{~min}$ are relatively low, which are then significantly increased at HRT of $20 \mathrm{~min}$. And a further increase in the HRT results in a higher removal efficiency. Although the removal efficiency can be up to $93.5 \%$ with the HRT of $60 \mathrm{~min}$, the corresponding unit energy consumption climbs to a much higher value. Thus, from a practical point of view, the HRT satisfying both removal and energy efficiency should be applied. In our three-dimensional electrochemical reactor, the value of HRT was chosen as $20 \mathrm{~min}$ in the subsequent experiments.

\subsection{Effects of initial $\mathrm{BrO}_{3}{ }^{-}$concentration and dissolved organic matter (DOM)}

The effect of initial $\mathrm{BrO}_{3}{ }^{-}$concentration on the reduction of $\mathrm{BrO}_{3}{ }^{-}$and generation of $\mathrm{Br}^{-}$is presented in Fig. 6 with the current density of $0.9 \mathrm{~mA} / \mathrm{cm}^{2}$ and HRT of $20 \mathrm{~min}$. It is observed that the rates of $\mathrm{BrO}_{3}{ }^{-}$reduction and $\mathrm{Br}^{-}$generation increase slightly with the increase of initial $\mathrm{BrO}_{3}{ }^{-}$concentration. Zhao et al. (2014) reported that the electrocatalytic reduction of haloacetic acids (HAAs) on the Pd-modified carbon electrode would be enhanced by increasing the initial HAAs concentration. Chen et al. (2010) found that increasing initial $\mathrm{BrO}_{3}{ }^{-}$concentration from 0.08 to $0.39 \mathrm{mM}$ led to the increase of the initial $\mathrm{BrO}_{3}{ }^{-}$reduction rate from 2.8 to $10.7 \mathrm{~m} \mathrm{Mg} \mathrm{Cat}{ }^{-1} \mathrm{~h}^{-1}$, and the $\mathrm{BrO}_{3}{ }^{-}$reduction by catalytic hydrogenation over supported Pd catalyst was controlled by the adsorption of $\mathrm{BrO}_{3}{ }^{-}$. In this case, eq (6) suggests that the rate of $\mathrm{BrO}_{3}{ }^{-}$reduction depends on both $\Theta_{\mathrm{H}}$ and $\Theta_{\mathrm{BrO}_{3}^{-}}$. It can be rationally deduced that the $\mathrm{BrO}_{3}{ }^{-}$coverage $\left(\Theta_{\mathrm{BrO}_{3}^{-}}\right)$should be proportional to the concentration of $\mathrm{BrO}_{3}{ }^{-}$in the bulk electrolyte. The electrochemical reaction is accelerated in the high concentration of $\mathrm{BrO}_{3}{ }^{-}$due to its limitation by the $\mathrm{BrO}_{3}{ }^{-}$ diffusion. However, in the low $\mathrm{BrO}_{3}{ }^{-}$concentration, a high removal efficiency can also be achieved in practice. It should be noticed that the reduction of $\mathrm{BrO}_{3}{ }^{-}$proceeds with a weak physical adsorption process rather than a chemisorption process, since nearly no $\mathrm{BrO}_{3}{ }^{-}$removal in the reactor was observed without the applied currents (shown in Fig. S3). This result also indicates the electrocatalytic reduction was the primary process for $\mathrm{BrO}_{3}{ }^{-}$removal in this study. Sagiv (1980) reported the similar adsorption of the dye and of the arachidic acid on the solid substrate, which was considered to be a reversible process involving relatively weak physical forces.

Considering the ubiquitous presence of DOM in surface waters, the electrochemical reduction of $\mathrm{BrO}_{3}{ }^{-}$with various concentrations of DOM measured as TOC was performed to assess the impact of DOM on the $\mathrm{BrO}_{3}{ }^{-}$reduction (Fig. 7). It is observed that the rate of $\mathrm{BrO}_{3}{ }^{-}$electro-reduction decreases with increasing the TOC concentration. When the DOM concentration increased from 0 to $5 \mathrm{mg} / \mathrm{L}$, the corresponding removal efficiency was reduced from $70.1 \%$ to $55.85 \%$. The similar inhibition effect on Pd-catalytic hydrodeoxygenation was observed by Chaplin et al. (2006). It was pointed out in their study that in the presence of $3.3 \mathrm{mg} / \mathrm{L}$ as TOC of humic acid, the reduction rate of nitrate by $\mathrm{H}_{2}$ with an aluminasupported $\mathrm{Pd}-\mathrm{Cu}$ catalyst decreased by $83 \%$ and strong adsorption of humic acid on the catalysts was observed in the reaction. In our case, the DOM sorption test with the threedimensional electrochemical reactor was conducted. As can be seen from the inset plots, the Pd-rGO/C cathode and PdrGO/GAC adsorbed $4.7 \%$ and $13.5 \%$ of the $2 \mathrm{mg} / \mathrm{L}$ and $5 \mathrm{mg} / \mathrm{L}$ $\mathrm{DOM}$ in $20 \mathrm{~min}$, respectively. This result indicates that DOM sorption was promoted with the increase of DOM concentration. Consequently, the sorption of DOM molecules on the catalytic active sites would suppress the electro-reduction of $\mathrm{BrO}_{3}{ }^{-}$and retard the reduction rate.

\subsection{Treatment of $\mathrm{BrO}_{3}^{-}$-contaminated tap water}

Treatment of $\mathrm{BrO}_{3}{ }^{-}$-contaminated tap water by the threedimensional electrochemical reactor with $\mathrm{Pd}-\mathrm{rGO} / \mathrm{C}$ cathode and Pd-rGO/GAC for the continuous running was conducted to clarify its applicability in a realistic water matrix. The water quality of the Beijing tap water was provided as in Table S2. The initial concentration of $\mathrm{BrO}_{3}{ }^{-}$was $20 \mu \mathrm{g} / \mathrm{L} 46.9 \mathrm{mg} / \mathrm{L} \mathrm{Ca}^{2+}$ and $20.9 \mathrm{mg} / \mathrm{L} \mathrm{Mg}^{2+}$ were included in the tap water. As

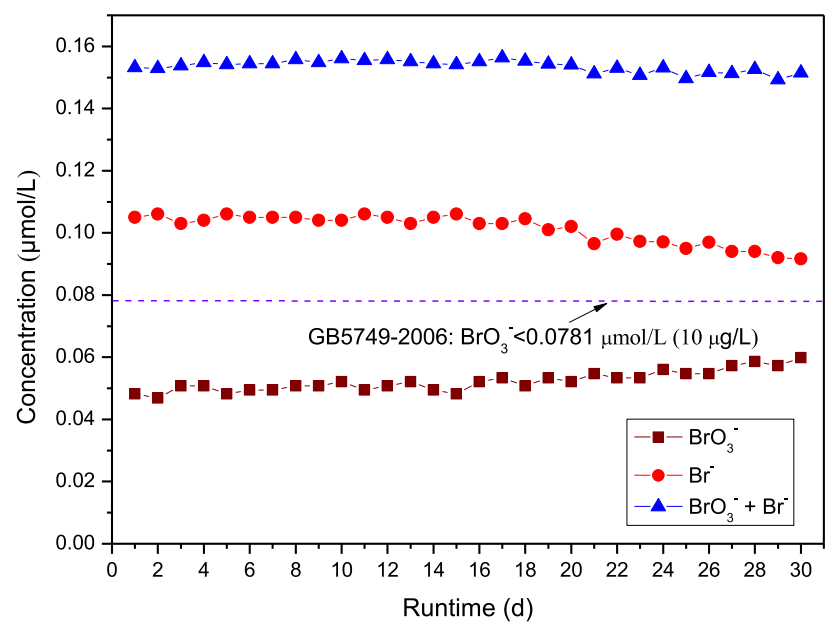

Fig. 8 - Variation in concentrations of bromine species in tap water during the continuous running $\left(0.54 \mathrm{mg} / \mathrm{cm}^{2} \mathrm{Pd}-\right.$ rGO/C cathode, $2.93 \mathrm{wt} \% \mathrm{Pd}-\mathrm{rGO} / \mathrm{GAC}$; initial $\mathrm{BrO}_{3}$ concentration $=20 \mu \mathrm{g} / \mathrm{L}$; current density $=0.9 \mathrm{~mA} / \mathrm{cm}^{2}$; $\mathrm{HRT}=20 \mathrm{~min} ; \mathrm{Ca}^{2+}$ concentration $=46.9 \mathrm{mg} / \mathrm{L}, \mathrm{Mg}^{2+}$ concentration $=20.9 \mathrm{mg} / \mathrm{L}$ ). 
presented in Fig. 8, $\mathrm{BrO}_{3}{ }^{-}$concentration remains nearly constant at $0.049 \mu \mathrm{mol} / \mathrm{L}(6.3 \mu \mathrm{g} / \mathrm{L})$ from 1 to $15 \mathrm{~d}$, and then increases progressively to $0.058 \mu \mathrm{mol} / \mathrm{L}(7.5 \mu \mathrm{g} / \mathrm{L})$ in the remaining 15 days. Meanwhile, $\mathrm{Br}^{-}$concentration is found to be varied with time at the relatively constant amount of total $\mathrm{Br}\left(\left[\mathrm{BrO}_{3}{ }^{-}\right]+\left[\mathrm{Br}^{-}\right]\right)$. This indicates that almost all of the decreased $\mathrm{BrO}_{3}{ }^{-}$is converted to $\mathrm{Br}^{-}$in the electrochemical reactor. Owing to the production of $\mathrm{OH}^{-}$by eqs (1) and (3), the effluent $\mathrm{pH}$ is detected to be in the range of $8.2-8.5$, slightly higher than the influent $\mathrm{pH}$ of 7.7-7.9. However, the $\mathrm{pH}$ at the interface may easily be higher than that in the bulk solution (12 or even higher). The electrocatalytic reduction of $\mathrm{BrO}_{3}{ }^{-}$ with various $\mathrm{pH}$ values was performed in a batch mode in order to explore the $\mathrm{pH}$ effect on $\mathrm{BrO}_{3}{ }^{-}$removal in the threedimensional reactor. As can be seen from Fig. S4, the rate of $\mathrm{BrO}_{3}{ }^{-}$reduction is successively decreased with increase of the $\mathrm{pH}$ from 6.6 to 12.7. There is no significant variation in the removal efficiency of $\mathrm{BrO}_{3}{ }^{-}$under $\mathrm{pH}$ from 6.6 to 12.7, indicating that the reduction of $\mathrm{BrO}_{3}{ }^{-}$could be performed well under a wide $\mathrm{pH}$ range. Especially for the continuous running, the neutral tap water was pumped through the reactor from the bottom to the top, which might serve to reduce the sharp increase in local pH at the interface, and thereby reducing the negative effect on $\mathrm{BrO}_{3}{ }^{-}$reduction. Compared with that in the influent, the concentration of $\mathrm{Ca}^{2+}$ and $\mathrm{Mg}^{2+}$ in the effluent is decreased by $46-55 \%$ and by $56-63 \%$, respectively, which can be ascribed to the increase of the local $\mathrm{pH}$. The dissolved $\mathrm{Ca}^{2+}$ and $\mathrm{Mg}^{2+}$ are partly transformed to calcium and magnesium carbonate or hydroxide deposits during the process, which can take up the active sites of the Pd catalysts. The energy cost is calculated to be $0.031 \mathrm{KWh} / \mathrm{mg}$, which is slightly lower than
Table 1 - BET analysis of GAC, Pd/GAC and Pd-rGO/GAC particles.

\begin{tabular}{lccc} 
& $\begin{array}{c}\text { Specific surface } \\
\text { area }\left(\mathrm{m}^{2} / \mathrm{g}\right)\end{array}$ & $\begin{array}{c}\left(\mathrm{cm}^{3} / \mathrm{g}\right) \\
(\mathrm{nm})\end{array}$ \\
\hline GAC & 1645 & 0.863920 & 3.8880 \\
Pd/GAC & 1433 & 0.661664 & 4.2665 \\
Pd-rGO/GAC & 1389 & 0.629242 & 4.3210 \\
Pd-rGO/GAC & 1356 & 0.603741 & 4.3415 \\
$\quad$ & & & \\
\hline
\end{tabular}

that for $\mathrm{BrO}_{3}{ }^{-}$-contaminated deionized water. Throughout the continuous running, $\mathrm{BrO}_{3}{ }^{-}$in the effluent is reduced below $10 \mu \mathrm{g} / \mathrm{L}$ within HRT of $20 \mathrm{~min}$. Thus, electro-reduction of $\mathrm{BrO}_{3}{ }^{-}$ in the electrocatalytic system has the potential for application to tap water treatment in some specific cases.

Fig. 9 shows SEM images of the Pd-rGO/C cathode and PdrGO/GAC before and after the electrochemical reaction in the tap water. It can be seen that abundant sphere-like electrodeposited Pd particles disperse evenly on the rGO-coated carbon fibers with ca. $40 \mathrm{~nm}$ in diameter (Fig. 9a). After reaction, Pd particles are observed to be covered by the tiny precipitates resulting from $\mathrm{Ca}^{2+}$ and $\mathrm{Mg}^{2+}$ in the tap water (Fig. 9b). As shown in Fig. 9c, the calcined Pd particles exhibit walnuts deposited on the rGO/GAC surface, with a much larger particle size than that of the electrodeposited Pd particles. However, the Pd particles remain nearly the same as those on the freshly prepared Pd-rGO/GAC after the electrocatalytic reduction process (Fig. 9d), indicating the precipitates on the Pd-rGO/GAC are far less than those on the PdrGO/C cathode.

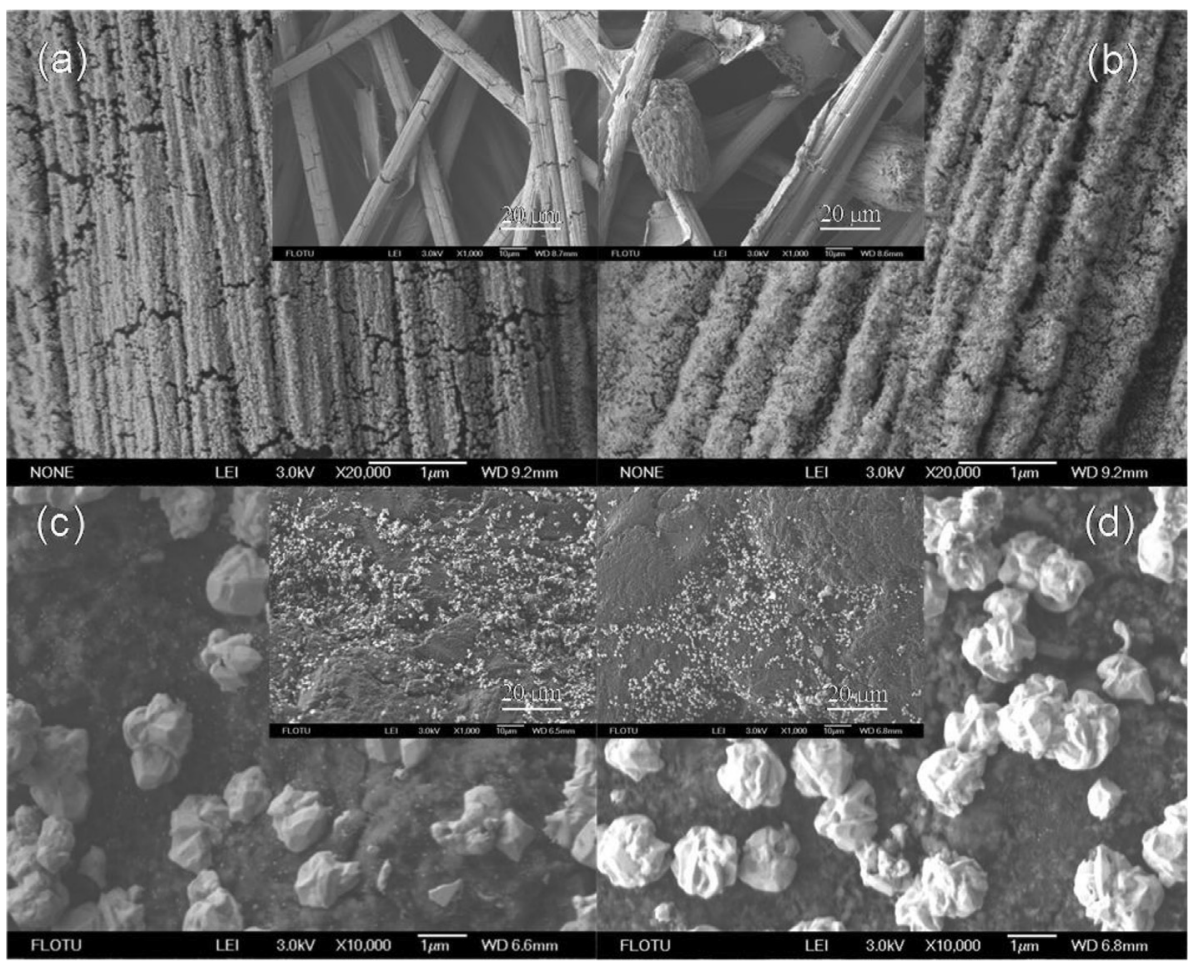

Fig. 9 - SEM images of (a) Pd-rGO/C cathode before the reaction, (b) Pd-rGO/C cathode after the reaction $30 \mathrm{~d}$, (c) Pd-rGO/GAC before the reaction, and (d) Pd-rGO/GAC after the reaction $30 \mathrm{~d}$. 
BET analysis of the GAC particles was performed. As shown in Table 1, the specific surface area and pore volume of the GAC decreased, whereas the pore diameter of the GAC increased after loading Pd particles. This may result from the blockage of some small pores by the Pd particles in GAC. For the Pd-rGO/GAC samples, addition of the rGO sheets further promoted the decrease in the specific surface area and pore volume. And after reaction, the three parameters were slightly changed due to the blockage of the precipitates during the continuous running.

Typical XPS survey spectra for the Pd-rGO/C cathode and $\mathrm{Pd}-\mathrm{rGO} / \mathrm{GAC}$ before and after the $\mathrm{BrO}_{3}{ }^{-}$reduction are presented in Fig. 10. The Pd 3d spectrum on the cathode is found to exhibit the spin-orbit doublet i.e. $3 d_{5 / 2}$ at $335.3 \mathrm{eV}$ and $3 d_{3 /}$ 2 at $340.5 \mathrm{eV}$ respectively, which are attributed to the presence of metallic palladium $\mathrm{Pd}^{0}$ (Fig. 10a). After the electroreduction process, three new absorbance peaks corresponding to $\mathrm{Mg}$ $\mathrm{KLL}$, Ca $2 \mathrm{p}_{3 / 2}$, and Ca $2 \mathrm{p}_{1 / 2}$ appear (Fig. 10b). The Ca $2 \mathrm{p}_{1 / 2}$ located at $351.8 \mathrm{eV}$ is assigned to $\mathrm{CaCO}_{3}$, while the $\mathrm{Ca} 2 \mathrm{p}_{3 / 2}$ centered at $347.4 \mathrm{eV}$ is the characteristic of $\mathrm{Ca}(\mathrm{OH})_{2}$ and $\mathrm{CaCO}_{3}$. The Mg KLL at $338.1 \mathrm{eV}$ excited by the auger electron of $\mathrm{Mg}$ species can be assigned to $\mathrm{MgO}$ and $\mathrm{Mg}(\mathrm{OH})_{2}$. The results suggest the precipitates of $\mathrm{Ca}(\mathrm{OH})_{2}, \mathrm{CaCO}_{3}, \mathrm{MgO}$ and $\mathrm{Mg}(\mathrm{OH})_{2}$ are generated and attached onto the $\mathrm{Pd}-\mathrm{rGO} / \mathrm{C}$ cathode during the treatment process. The similar binding energies for metallic Pd are detected in the Pd-rGO/GAC particles (Fig. 10c). Fig. 10d clearly shows that the peak intensities for $\mathrm{Ca} 2 \mathrm{p}$ and Mg KLL are much lower than those of the Pd-rGO/C cathode. Combined with the SEM analysis, it can be concluded that the precipitates are predominantly deposited on the $\mathrm{Pd}-\mathrm{rGO} / \mathrm{C}$ cathode. By contrast, only a small fraction of the precipitates are attached onto Pd-rGO/GAC. In our experiment the longlasting electrocatalytic activity can be maintained although the carbonates and hydroxides would inevitably cover the $\mathrm{Pd}$ catalysts, especially on the Pd-rGO/C cathode. These precipitates on the Pd-rGO/C cathode and Pd-rGO/GAC can be largely removed by the dilute $\mathrm{HCl}$, after which the high electrocatalytic activity can be regenerated (Zhao et al., 2014). The concentration of $\mathrm{Pd}^{2+}$ in the effluent was below the detection limit $(50 \mu \mathrm{g} / \mathrm{L})$ as measured by the ICP-OES, indicating the stability of the Pd-rGO/C cathode and Pd-rGO/GAC particles.

\section{Conclusions}

The present study showed that efficient reductive removal of $\mathrm{BrO}_{3}{ }^{-}$can be realized in the three-dimensional electrochemical reactor, by coupling Pd-rGO/C cathode and Pd-rGO/ GAC particles in the cathode cell. The significance of the rGO sheets and the synergistic effect of the Pd-rGO/C cathode and Pd-rGO/GAC were clearly demonstrated. The atomic $\mathrm{H}^{*}$ involved in the electroreduction process were determined by the ESR spin trapping. The Pd loading amounts on both PdrGO/C cathode and Pd-rGO/GAC were optimized. It could be deduced that the reaction rate was governed by the surface coverage of atomic $\mathrm{H}^{*}$ and adsorbed $\mathrm{BrO}_{3}{ }^{-}$. Considering the energy consumption and removal efficiency, the current density and HRT value was selected as $0.9 \mathrm{~mA} / \mathrm{cm}^{2}$ and $20 \mathrm{~min}$, respectively. DOM can inhibit the electrochemical reduction due to its sorption onto the catalyst surface sites.
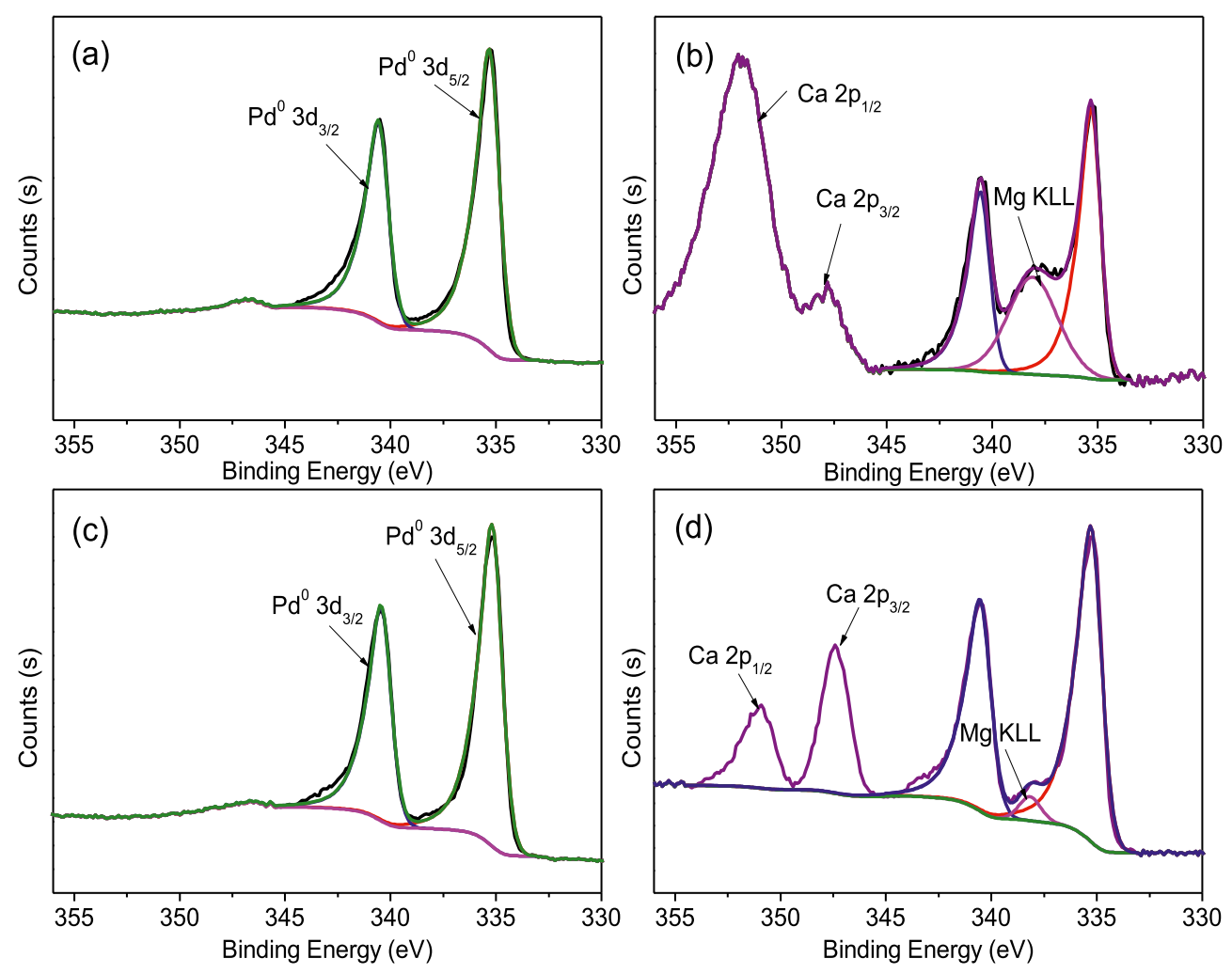

Fig. 10 - XPS analysis of (a) Pd-rGO/C cathode before the reaction, (b) Pd-rGO/C cathode after the reaction 30d, (c) Pd-rGO/GAC before the reaction, and (d) Pd-rGO/GAC after the reaction $30 \mathrm{~d}$. 
Despite the fact that precipitants of $\mathrm{Ca}(\mathrm{OH})_{2}, \mathrm{CaCO}_{3}, \mathrm{MgO}$ and $\mathrm{Mg}(\mathrm{OH})_{2}$ would predominantly deposited on the Pd-rGO/C cathode, the high efficiency for $\mathrm{BrO}_{3}{ }^{-}$removal by the electrocatalytic reduction process was observed for the $30 \mathrm{~d}$ treatment. The findings indicate that the three-dimensional electrochemical reactor may serve as a promising system for $\mathrm{BrO}_{3}{ }^{-}$reduction or other catalytic reduction of contaminants in water treatment.

\section{Acknowledgments}

This work was supported by National Natural Science Foundation of China (No. 51290282, 51478455, 51222802) and Key National Project "863" High Tech R\&D Program of China (No. 2012AA062604).

\section{Appendix A. Supplementary data}

Supplementary data related to this article can be found at http://dx.doi.org/10.1016/j.watres.2015.03.002.

\section{R E F E R E N C E S}

Allen, M.J., Tung, V.C., Kaner, R.B., 2009. Honeycomb carbon: a review of graphene. Chem. Rev. 110, 132-145.

An, W., Hong, J.K., Pintauro, P.N., 1998. Current efficiency for soybean oil hydrogenation in a solid polymer electrolyte reactor. J. Appl. Electrochem. 28, 947-954.

Butler, R., Godley, A., Lytton, L., Cartmell, E., 2005. Bromate environmental contamination: review of impact and possible treatment. Crit. Rev. Environ. Sci. Technol. 35 (3), 193-217.

Casella, I.G., Contursi, M., 2005. Electrochemical and spectroscopic characterization of a tungsten electrode as a sensitive amperometric sensor of a small inorganic ions. Electrochim. Acta 50, 4146-4154.

Chaplin, B.P., Roundy, E., Guy, K.A., Shapley, J.R., Werth, C.J., 2006. Effects of natural water ions and humic acid on catalytic nitrate reduction kinetics using an alumina supported $\mathrm{Pd}-\mathrm{Cu}$ catalyst. Environ. Sci. Technol. 40 (9), 3075-3081.

Chen, H., Xu, Z.Y., Wan, H.Q., Zheng, J.Z., Yin, D.Q., Zheng, S.R., 2010. Aqueous bromate reduction by catalytic hydrogenation over $\mathrm{Pd} / \mathrm{Al}_{2} \mathrm{O}_{3}$ catalysts. Appl. Catal. B Environ. 96 (3-4), 307-313.

Cheng, W., Dastgheib, S.A., Karanfil, T., 2005. Adsorption of dissolved natural organic matter by modified activated carbons. Water Res. 39, 2281-2290.

Comninellis, C., Chen, G., 2010. Electrochemistry for the Environment. Springer, New York.

Conner, W.C., Falconer, J.L., 1995. Spillover in heterogeneous catalysis. Chem. Rev. 95, 759-788.

Ding, L., Li, Q., Cui, H., Tang, R., Xu, H., Xie, X.C., Zhai, J.P., 2010. Electrocatalytic reduction of bromate ion using a polyanilinemodified electrode: an efficient and green technology for the removal of $\mathrm{BrO}_{3}^{-}$in aqueous solutions. Electrochim. Acta 55 (28), 8471-8475.

Huang, X., Wang, L.Y., Zhou, J.Z., Gao, N.Y., 2014. Photocatalytic decomposition of bromate ion by the UV/P25-graphene processes. Water Res. 57, 1-7.
Huang, X., Zeng, Z.Y., Fan, Z.X., Liu, J.Q., Zhang, H., 2012. Graphene-based electrodes. Adv. Mater. 24, 5979-6004.

Kim, D., Ahmed, M.S., Jeon, S., 2012. Different length linkages of graphene modified with metal nanoparticles for oxygen reduction in acidic media. J. Mater. Chem. 22, 16353-16360.

Kirisits, M.J., Snoeyink, V.L., Inan, H., Chee-Sanford, J.C., Raskin, L., Brown, J.C., 2001. Water quality factors affecting bromate reduction in biologically active carbon filters. Water Res. 35 (4), 891-900.

Kishimoto, N., Matsuda, N., 2009. Bromate ion removal by electrochemical reduction using an activated carbon felt electrode. Environ. Sci. Technol. 43 (6), 2054-2059.

Kong, W.P., Wang, B., Ma, H.Z., Gu, L., 2006. Electrochemical treatment of anionic surfactants in synthetic wastewater with three-dimensional electrodes. J. Hazard. Mater. 137, 1532-1537.

Li, A.Z., Zhao, X., Hou, Y.N., Liu, H.J., Wu, L.Y., Qu, J.H., 2012. The electrocatalytic dechlorination of chloroacetic acids at electrodeposited Pd/Fe-modified carbon paper electrode. Appl. Catal. B Environ. 111-112, 628-635.

Li, T., Farrell, J., 2001. Electrochemical investigation of the ratelimiting mechanisms for trichloroethylene and carbon tetrachloride reduction at iron surfaces. Environ. Sci. Technol. 35, 3560-3565.

Li, T.Y., Chen, Y.M., Wan, P.Y., Fan, M.H., Yang, X.J., 2010. Chemical degradation of drinking water disinfection byproducts by millimeter-sized particles of iron-silicon and magnesium-aluminum alloys. J. Am. Chem. Soc. 132 (8), 2500-2501.

Li, Y.M., Tang, L.H., Li, J.H., 2009. Preparation and electrochemical performance for methanol oxidation of Pt/graphene nanocomposites. Electrochem. Commun. 11, 846-849.

Lipkowski, J., Ross, P.N., 1998. Electrocatalysis. Wiley-VCH Publishers, New York.

Listiarini, K., Tor, J.T., Sun, D.D., Leckie, J.O., 2010. Hybrid coagulation-nanofiltration membrane for removal of bromate and humic acid in water. J. Membr. Sci. 365 (1-2), 154-159.

Liu, C., von Gunten, U., Croué, J.P., 2013. Chlorination of bromidecontaining waters: enhanced bromate formation in the presence of synthetic metal oxides and deposits formed in drinking water distribution systems. Water Res. 47, 5307-5315.

Mao, R., Zhao, X., Lan, H.C., Liu, H.J., Qu, J.H., 2014. Efficient electrochemical reduction of bromate by a Pd/rGO/CFP electrode with low applied potentials. Appl. Catal. B Environ. 160-161, 179-187.

Mao, X.H., Ciblak, A., Amiri, M., Alshawabkeh, A.N., 2011. Redox control for electrochemical dechlorination of trichloroethylene in bicarbonate aqueous media. Environ. Sci. Technol. 45, 6517-6523.

Mascia, M., Vacca, A., Palmas, S., 2012. Fixed bed reactors with three dimensional electrodes for electrochemical treatment of waters for disinfection. Chem. Eng. J. 211-212, 479-487.

Matos, C.T., Velizarov, S., Reis, M.A., Crespo, J.G., 2008. Removal of bromate from drinking water using the ion exchange membrane bioreactor concept. Environ. Sci. Technol. 42, $7702-7708$.

Mezyk, S.P., Cooper, W.J., Madden, K.P., Bartels, D.M., 2004. Free radical destruction of $\mathrm{N}$-nitrosodimethylamine in water. Environ. Sci. Technol. 38, 3161-3167.

Paschoal, F.M.M., Pepping, G., Zanoni, M.V.B., Anderson, M.A., 2009. Photoelectrocatalytic removal of bromate using $\mathrm{Ti}^{-} \mathrm{TiO}_{2}$ coated as a photocathode. Environ. Sci. Technol. 43, 7496-7502.

Radjenovic, J., Farre, M.J., Mu, Y., Gernjak, W., Keller, J., 2012. Reductive electrochemical remediation of emerging and 
regulated disinfection byproducts. Water Res. 46 (6), 1705-1714.

Sagiv, J., 1980. Organized monolayers by adsorption. 1. Formation and structure of oleophobic mixed monolayers on solid surfaces. J. Am. Chem. Soc. 102, 92-98.

Skunik, M., Kulesza, P.J., 2009. Phosphomolybdate-modified multi-walled carbon nanotubes as effective mediating systems for electrocatalytic reduction of bromate. Anal. Chim. Acta 631, 153-160.

Sridhar, V., Kim, H.J., Jung, J.H., Lee, C.G., Park, S.J., Oh, I.K., 2012. Defect-engineered three-dimensional graphene-nanotubepalladium nanostructures with ultrahigh capacitance. ACS Nano 6, 10562-10570.

Sun, C., Baig, S.A., Lou, Z.M., Zhu, J., Wang, Z.X., Li, X., Wu, J.H., Zhang, Y.F., Xu, X.H., 2014. Electrocatalytic dechlorination of 2, 4-dichlorophenoxyacetic acid using nanosized titanium nitride doped palladium/nickel foam electrodes in aqueous solutions. Appl. Catal. B Environ. 158-159, 38-47.

Wei, L.Y., Guo, S.H., Yan, G.X., Chen, C.M., Jiang, X.Y., 2010. Electrochemical pretreatment of heavy oil refinery wastewater using a three-dimensional electrode reactor. Electrochim. Acta 55, 8615-8620.

Weinberg, H.S., Delcomyn, C.A., Unnam, V., 2003. Bromate in chlorinated drinking waters: occurrence and implications for future regulation. Environ. Sci. Technol. 37 (14), 3104-3110.
Yang, B., Yu, G., Huang, J., 2007. Electrocatalytic hydrodechlorination of 2, 4, 5-trichlorobiphenyl on a palladium-modified nickel foam cathode. Environ. Sci. Technol. 41, 7503-7508.

Yen, M.Y., Teng, C.C., Hsiao, M.C., Liu, P.I., Chuang, W.P., Ma, C.C.M., Hsieh, C.K., Tsai, M.C., Tsai, C.H., 2011. Platinum nanoparticles/graphene composite catalyst as a novel composite counter electrode for high performance dye -sensitized solar cells. J. Mater. Chem. 21, 12880-12888.

Zelmanov, G., Semiat, R., 2014. Boron removal from water and its recovery using iron $\left(\mathrm{Fe}^{+3}\right)$ oxide/hydroxide-based nanoparticles (NanoFe) and NanoFe-impregnated granular activated carbon as adsorbent. Desalination 333, 107-117.

Zhang, M., Bacik, D.B., Roberts, C.B., Zhao, D.Y., 2013. Catalytic hydrodechlorination of trichloroethylene in water with supported CMC-stabilized palladium nanoparticles. Water Res. 47, 3706-3715.

Zhao, X., Li, A.Z., Mao, R., Liu, H.J., Qu, J.H., 2014. Electrochemical removal of haloacetic acids in a three-dimensional electrochemical reactor with Pd-GAC particles as fixed filler and Pd-modified carbon paper as cathode. Water Res. 51, 134-143. 